\title{
LEGAL RELATIONSHIPS ON THE LOCAL BUDGETS REVENUE
}

\section{Hnatovska A. I.}

\section{INTRODUCTION}

Modern Ukrainian society is going through a difficult phase of political, economic and social transformation. The development of market relations and the sustainable functioning of the market system at the present stage require a unified approach to address many issues and necessitate the development of new approaches in financial and legal theory and practice to the formation of relations between the state and local budgets.

At present, the formation of the revenue part of local budgets is under quite difficult conditions. Despite a number of effective financial policy steps taken recently to improve local budgets, budgets remain incapable of responding to the pressing challenges of regional development.

The lack of financial autonomy of local self-government and instability of revenue sources have become a problem of national importance. The problems of legal regulation of the implementation of local budgets on revenues require research in the light of the signing and ratification by the Verkhovna Rada of Ukraine of the European Charter of Local Self-Government on November 6, 1996. In this respect, the issues of financing by local authorities of their own and delegated powers remain uncoordinated, the delineation of the powers of the subjects of implementation of local budgets by revenues and the Budget Code of Ukraine adopted on July 8, 2010 are not defined.

Finance is a rather complex multifaceted social phenomenon characterized by different features and manifestations. Local finance is a complex and ambiguous phenomenon. In Ukraine, the process of local finance formation, which began in the 1990s, causes significant institutional changes in the entire financial system of the country.

A particularly important role in the local finance hierarchy belongs to the Institute of Local Budgets. Local budgets themselves are the funds that mobilize the bulk of the financial resources needed to provide public services.

Therefore, ensuring the independence of local authorities in the formation of these funds is an extremely important task that must be solved in the process of establishing the local finance system and defining its structure.

The totality of legal relations for the implementation of local budgets is a whole system that consists in the formation, distribution and use of financial resources to provide local authorities with the functions and tasks assigned to them by local authorities (transferred to local authorities within the limits 
of local interests), and delegated (entrusted to local authorities by central government).

The following institutions are formed in their structure: independent local budgets, extra-budgetary, currency and trust funds of local selfgovernment bodies, communal ownership, local taxes and fees, municipal credit, utility payments, finances of public utilities.

Local budget execution is the activity of entities authorized by law to ensure full and timely mobilization of local budget revenues, both in general and at each source, as well as timely, complete, continuous and targeted funding for the programs and activities envisaged by them.

Activities aimed at ensuring the efficient implementation of local budgets focus on all other stages of the budget process, including drafting, reviewing and approving local budgets, and drafting and approving budget reports on budget execution.

It should be noted that the process of implementation of local budgets is the most important, complex and long-lasting stage of the budget process, which depends on ensuring the financing of priority sectors of the economy, social sphere, implementation of programs and activities of socio-economic development of the region and the country as a whole.

Relationships to replenish local budget revenues are a specific type of budgetary relationships that have their own, inherent features and characteristics. By their nature, they are managerial relationships and aim at matching the actual local budget revenues to the indicators planned in the local budget.

\section{The genesis of scientific views on legal relationships for the formation of local budgets revenue}

Legal relationships on the local budgets revenue have always aroused increased public interest and have been the subject of scientific research in legal and economic science.

Works of domestic scientists - representatives of financial law science of the second half of the nineteenth - early twentieth centuries indicates significant interest in the problem of revenue mobilization in local budgets.

The revitalization of such theoretical developments was conditioned by the development of market relations in the state and local economies, the growing role of administrative-territorial communities in meeting local and state needs, reforming the fiscal legislation, which required appropriate scientific substantiation.

The study of the implementation of local budget revenue part was carried out in the context of political, economic and financial analysis of the financial activity of the state and local governments under the influence of the rejection of economic liberalism and the gradual adoption of the ideals of the welfare state. 
Analysis of scientific works of the XIX century. gives grounds to state the existence of different approaches to determining the nature of local budget revenues. The use of historical, comparative and evolutionary methods in the study of the development of the economy led to their interpretation as a collection of all material income, not just money.

This approach was the rationale for public policy, which involved the active use of natural resources to cover part of state and local expenditures.

With the development of market relations, a new vision of the legal nature of local budget revenues has emerged as a way of forming decentralized funds to meet local collective interests.

Representatives of finance-law science of the second half of the nineteenth century saw a relic past in non-monetary income. They believed that as a result of the evolutionary development of the economy, "a new long time exists alongside the remnants of the old" to "full maturity of the state's production capacity" ${ }^{1}$, as a result, the outdated loses its significance and dies.

Supporters of such a vision of the development of economic forms of financial economy were I. Tarasov, V. Lebedev, D. Lviv.

However, the sustainability and preservation of such legal vestiges in the public practice has forced scientists to "not ignore the imperfect beginnings of tax" in the form of natural debt and to consider primarily their monetary equivalent as part of local budget revenues or as a peculiar addition to them.

The Ukrainian scientist K. Wobly, who considered income to be primarily part of local economy, and not just the financial policy of local selfgovernment, held a similar position ${ }^{2}$.

Such an interpretation gives reason to consider them as part of a complex economic mechanism that influenced the level of production, the peculiarities of distribution and consumption of a public product in a certain territory.

I. Gorlov, G. Tiktin, G. Sidorenko, V. Totomianz also saw similar views on this issue: workforce recovery through satisfaction of collective interests, accumulation of capital through the creation of public utilities, efficient use of public property through long-term rental property through a tender, etc.

It should be noted that the majority of representatives of financial law science focused on the formal nature of local budget revenues, which included only resources legally allocated by the state for the benefit of a particular

1 Львов Д. Курс финансового права. Казань : Тип. Император. ун-та, 1887. 521 c. - C. 93.

2 Воблый К.Г. Начальный курс политической экономии : (История, теория, финансы) : пособ. для коммерч., технич. училищ и для самообразов. с 6 диаграммами в тексте / К.Г. Воблый ; Киев. юрид. ин-т. Киев : Т-во печ. и изд. дела авт.-изд. «Голос», 1918. 252 c. C. 249. 
territorial community. According to scientists, their legal nature reduced the misuse of the financial administration and made it easier to pay taxpayer ${ }^{3}$.

The right to form an income base was defined by law and was considered as a concession by the state as part of its own right in the form of fixed income in favor of a lower-level budget.

In this regard, scientists were noted for the negative impact of the absence of local taxes due to the inability to predict the tax policy of the state in the long term, and consequently the availability of such tax sources in local budgets and non-economic methods of managing them.

This was due to the fact that local governments did not try to preserve their tax and production potential.

It should be noted that the theoretical vision of revenue assignment changed. In the previous historical period, attention was paid to their fiscal value and satisfaction of the state's political interests above all.

In the theory of local finance in the second half of the nineteenth century dominated the idea about primacy of individual and collective needs, which should be directed by public activity, not vice versa.

In the financial law literature of the late nineteenth century was the opinion that the formation of the revenue part of local budgets should be made on the basis of the same sources that form the revenue part of the state budget.

Positively assessing the reforms of the 60's of the XIX century. in the budget and tax legislation and local governments, scientists - representatives of financial law science in the second half of the nineteenth - early twentieth centuries pointed to a number of measures necessary for the functioning of local finance as a holistic systems. Such urgent measures included, first of all, the need to create their own system of local income.

Analyzing the scientific perspectives on the concept and nature of local budget execution, we can conclude that the vast majority of scientists understand this activity as the implementation of two related procedures, namely the transfer of revenues to the budget and finance budgeted expenditures.

In particular, the financial vocabulary budget execution is understood as the realization of receiving, storing and issuing budget, accounting and reporting in the implementation of the budget ${ }^{4}$.

According to professor L.K. Voronova perform budget is to collect revenue, which is the minimum amount set by law on the state budget or the local budget decision, and finance charges ${ }^{5}$.

${ }^{3}$ Иловайский С.И. Краткий учебник финансового права Одесса : Типография шт. войск Одесского военного округа, 1893. 297 с. С. 116.

${ }^{4}$ Загородній А.Г. Фінансовий словник. / Загородній А.Г., Вознюк Г.Л., Смовженко Т.С. Львів : Центр Європи, 1997. 576 с. С. 76.

${ }^{5}$ Фінансове право : підручник / Л.К. Воронова. - Х. : Консум, 1999. - 496 с. - С. 180. 
Budget implementation is the stage of the budget process that is ensured by the activities of the legislative and executive bodies, which have drafted and approved many regulations on revenue and expenditure planning. With the beginning of the new fiscal year, you must implement the plan for revenue and expenditure that became law ${ }^{6}$.

The purpose of implementing the budget is to achieve consistency between actual budget revenues, expenditures and the legal rules governing the sources and amounts of these revenues, as well as the directions and amounts of expenditures. Based on the stated purpose of the budget execution, it is possible to identify a correspondence between the actual results of the actions of the obliged entities with the budget funds and the set of budget-legal norms of the indicators of the budget act regarding the enrollment and use of funds for certain areas of financing in the prescribed amount.

The use of these budgetary rules implies the restraint from other actions, including the spending of budgetary funds for purposes not provided for in the budget act or provided for, but to a different extent. Recent actions are a budget offense for which responsibility is provided in accordance with Chapter 18 of the Budget Code of Ukraine ${ }^{7}$.

Investigating the organization of budget execution, O.D. Vasylik and K.V. Pavlyuk noted that "the budget execution system is intended to carry out operational management and control over the formation of budget revenues and their intended use, in accordance with the revenues and expenditures of the approved budget" ${ }^{8}$.

Definitions of budget execution, which characterize the narrow interpretation of this stage, are given by Romanenko O. and Oparin V. "... mobilize financing planned revenues and expenditures foreseen" ${ }^{9}$.

Narrower definitions of budget execution, as opposed to expanded ones, characterize this stage of the budget process more precisely, since they focus on its most important aspects. Budget implementation is an organized process of mobilizing budget revenues and making expenditures in accordance with the state budget law and local government decisions on local budgets ${ }^{10}$.

${ }^{6}$ Воронова Л.К. Фінансове право : підручник / Л.К. Воронова. К. : Прецедент; Моя книга, 2006. 448 с. С. 168.

${ }^{7}$ Чернадчук В.Д. Стан та перспективи розвитку бюджетних правовідносин в Україні : монографія / В.Д. Чернадчук. Суми : ВТД «Університетська книга», 2008. 456 с. C. 240-241.

${ }^{8}$ Василик О.Д. Бюджетна система України : підручник / О.Д. Василик, К.В. Павлюк. - К. : Центр навч. л-ри, 2004. 544 с. С. 476.

${ }_{9}^{9}$ Романенко О.Р. Фінанси : підручник / О.Р. Романенко К. : Центр навч. літератури, 2006. 312 c. C. 156.

${ }^{10}$ Економічна енциклопедія : у 3 т. / відп. ред. С.В. Мочерний та ін. К. : Вид-во центр «Академія». Т. 1. 2000. 864 с. С. 188. 
Describing the peculiarities of budgetary and procedural norms of budget execution, A.G. Paul notes that the rules not only define the procedure itself, but also provide for financial control ${ }^{11}$.

The author of the study supports the position of V.D. Chernadchuk, that it is advisable to speak about the dual nature of these legal relationships in the context of the combination of substantive and procedural, the relationship between which is manifested in the legal relations of budget execution ${ }^{12}$. The essence of these relationships lies in the implementation of substantive rules of budgetary law contained in the law or decision on the budget, by performing procedural actions determined by the procedural rules of budgetary law. Substantive legal rules are enforced and budgetary procedural ones are implemented within a combination of substantive and procedural budgetary relationships, which together constitute the only comprehensive legal relationship of budget execution, where the unity of substantive and procedural is manifested.

\section{Legal relationships on the local budgets revenue as a kind of budgetary relationship}

Budget implementation relations exist at the state and local level and therefore it is possible to distinguish legal relations of state budget execution and legal relations of execution of local budgets. These relationships are not isolated from each other and do not exist independently of each other.

The legal implementation of state and local budgets is regulated by different chapters of the Budget Code, although some provisions of the code are general, for example, regarding the legal status of spending units.

Despite the presence of paragraph 3 of Art. 7 of the Budget Code of Ukraine of the principle of independence, we can speak of the dependence of the relationship of execution of local budgets on the relationship of execution of the state budget, which is the presence of the so-called "binding" relationship, which are called in the budget legislation and the legal literature of intergovernmental relations.

A characteristic feature of the legal relations of budget execution is, first of all, their functional purpose - budget financing of the provision of tasks and functions, which are carried out by state authorities and local selfgovernment bodies.

Therefore, the budget execution relationship has a managerial nature and is a form of budget execution management.

${ }^{11}$ Пауль А.Г. Процессуальные нормы бюджетного права / А.Г. Пауль. СПб : Питер, 2003. 208 c. C. 107.

12 Чернадчук В.Д. Стан та перспективи розвитку бюджетних правовідносин в Україні : монографія / В.Д. Чернадчук. Суми : ВТД «Університетська книга», 2008. 456 с. С. 241. 
The overall organization and management of the implementation of the State Budget of Ukraine is carried out by the Ministry of Finance of Ukraine, which also coordinates the activities of budget process participants, and at the local level the organization, management and coordination are carried out by local financial authorities ${ }^{13}$.

The implementation of local budgets by revenue is part of the budgetary activity and is also a procedure of the third stage of the budgetary process. The legal connection of the participants arises and exists regarding the performance of the indicators of the revenue part of the local budget, that is, about the crediting of revenues to this budget (cash receipts), and not about the actual relations, the purpose of which is to secure cash receipts in the amount established by the budget act ${ }^{14}$.

A consistent set of actions of participants in the procedure of execution of the budget for income is aimed at achieving a specific result - the implementation of the local budget for income, that is, ensuring the cash flow to the budget, which is the result of the actions of participants in a materialized form ${ }^{15}$.

Thus, the relations of execution of local budgets by revenues are the relationships that are formed between subjects of budgetary law regarding the timely and complete receipt of money in the local budget revenue of a certain level for the budgetary financing of the provision of tasks and functions performed by public authorities and local authorities municipality.

Relationships to the revenue side of local budgets are a type of budgetary relations, and their characteristics are common.

In order to properly identify the relationship between local budget performance on revenue and other elements of the budgetary relationship, they must be characterized by their own characteristics, which are:

the process and grounds for their occurrence, development, change and termination are determined by the norms of the Budget Code of Ukraine, which are directly implemented in these relations;

represent the connection of clearly defined entities;

the organizational function in the legal relations concerning local budget revenues consists in a clear sequence of actions performed by all subjects of the specified legal relations in the development of the draft budget, determining its revenues, the procedure for their receipt and entry into the treasury account;

${ }^{13}$ Гнатовська А.І. Загальна характеристика об'єктів бюджетних правовідносин. Європейські перспективи. 2011. № 1. С. 111

${ }^{14}$ Правовий статус суб'єктів виконання місцевих бюджетів за доходами : монографія / Т.А. Латковська, А.І. Гнатовська. - Одеса : Фенікс, 2014. - 228 с.

${ }^{15}$ Latkovska T., Kasianenko L.M. Procedural norms in the financially-legal regulation Public finance: legal aspects: Collective monograph Riga : Izdevnieciba «Baltija Publishing». 2019. P. 88. 
revenues to local budgets come from taxes, fees, payments, duties, this is the property feature of the relationship, all of the above are payments paid by individuals and legal entities;

the imperative nature of the relationship on the local budgets revenue it is manifested in the fact that the subjects entering into these legal relationships do not have a choice of behaviors, they are obliged to act in accordance with the rules of the legislation that regulates it;

state power feature of the relationship on the local budgets revenue is that the central executive body that provides for the formation of the state budget policy, proves to the Council of Ministers of the Autonomous Republic of Crimea, local state administrations, executive bodies of the respective local councils the peculiarities of calculating budget projects for the next budget period.

Imperative relationship of execution of local budgets on income arises from the fact that budgetary relations are regulated by the imperative method $^{16}$, which is objectively necessary because it really promotes and ensures timely and full flow of funds into the state funds, their proper distribution and redistribution, as well as their strictly targeted and expedient use in accordance with the rules of law ${ }^{17}$.

Using this method, public authorities require unconditional subordination and unconditional execution of their prescriptions from other bodies subordinate to them.

Participants in the budget process are required not to subordinate, but to comply with and not violate the requirements of budgetary rules ${ }^{18}$. Budget relations are characterized by the fact that they have no equality of parties, because the state has to submit to the will of other subjects of these social ties in order to achieve the common, public interest, that is, they are characterized by a state-power character.

Relations on the revenue side of local budgets, as budgetary relations in general, are governed solely by the norms of legislative acts, that is, the state gives the budgetary legal relations the highest level of legal protection, because no body, except the Verkhovna Rada of Ukraine, is able to regulate budgetary relations. The law on the budget or the decision on the local budget for each current year is made exclusively by the deputies of Ukraine.

In this connection, characterizing the place of legal relations concerning the execution of local budgets by revenues in the system of budgetary relations, it should first of all proceed from the fact that budgetary

\footnotetext{
${ }^{16}$ Алисов Е.А. Финансовое право Украины : учеб. пособ. Х. : Эспада, 2000. 288 с. С. 26.

${ }^{17}$ Дмитрик О.А. Содержание и классификация финансовых правоотношений : монография / О.А. Дмитрик ; под ред. Н. П. Кучерявенко. Х. : Легас, 2004. 160 с. С. 30.

${ }^{18}$ Музика-Стефанчук О.А. Органи публічної влади як суб'єкти бюджетних правовідносин / О.А. Музика-Стефанчук. Хмельницький : Вид-во Хмельн. ун-ту управл. та права, 2011. 384 с. - С. 43-44.
} 
relations are realized in the process of budgetary activity of authorities of state and local self-government, which are regulated by the rules of budgetary law and are drawn up on budget revenue generation, distribution and spending.

The system of budgetary relationships consists of relationships that are aimed at budgeting, approval, subsequent implementation, monitoring of implementation, reporting on the fact of implementation.

V.D. Chernadchuk offers a three-tier system of budgetary legal relations. At the first level, it identifies the main and ancillary budgetary relationships; at the second level, the main ones are divided into the legal relations between the implementation of the state and local budgets.

Ancillary budgetary relationships are divided into rulemaking, budgetary and security. At the third level, the budgetary relations of the second level are divided into: legal relations of budget execution (budget forming, budgetary allocations and budget transfers); rulemaking budget relations are divided into planning relationships and legal rulings of budget rulemaking; control budgetary relationships are divided into preventive, current and final; budgetary protective relations are divided into budgetary torts, legal relations of proceedings in the case of budgetary offenses and legal relations of budgetary responsibility ${ }^{19}$.

At the legislative level, not only the list of subjects of the legal relationship, but also their powers and the procedure for exercising these powers, should be clearly stated.

At present, Art. 50 and 78 of the Budget Code $^{20}$ of Ukraine only enumerates the subjects of the execution of the state budget on revenues: the Ministry of Finance of Ukraine and the State Treasury of Ukraine, and in the legal relations of the implementation of local budgets on revenues - local selfgovernment bodies, local executive bodies and territorial bodies of the State Treasury of Ukraine.

It should also be maintained that, despite the fact that the Budget Code of Ukraine stipulates that the collection authorities ensure timely and full receipt of taxes and levies (compulsory payments) and other revenues in accordance with the legislation in accordance with the law, their subjects of these relationships are inappropriate.

Today, in the science of financial law, there is a need to differentiate between tax and budget relationships, so the relationship to ensure the receipt of mandatory payments to the budget is tax, and the reason for their termination and the emergence of legal relations on the implementation of local budgets for income is the fact of receipt of funds in budget accounts for crediting receipts (receipts accounts).

${ }^{19}$ Чернадчук В.Д. Стан та перспективи розвитку бюджетних правовідносин в Україні : монографія / В.Д. Чернадчук. Суми : ВТД «Університетська книга», 2008. 456 с. С. 96.

${ }^{20}$ Бюджетний кодекс України від 08.07.2010 р. Відомості Верховної Ради Украйни. 2010. № 50-51. Ст. 572. 


\section{Control as a way of ensuring local budget revenues}

The result of the execution of the revenue budget is the complete and timely receipt of all planned revenues to the local budget, which makes it possible to report on its full implementation.

When revenues are received by local budgets, taxes and fees planned for the year are collected in accordance with the procedure approved by the budget and tax legislation, so the authorities are obliged to control these activities.

Financial control is a means of ensuring compliance with financial and planning discipline, as well as ensuring the effective implementation of local budgets. Financial control has always been a very important function of public administration.

And it is quite clear that it is through financial control that budgeting is effected both in terms of revenue and expenditure, since financial control is an effective tool in combating financial crime, a means of preserving state and communal property and funds, which is of particular importance for stage of formation of market relations in Ukraine.

The system of financial control over the implementation of budgets in Ukraine has been substantially reformed lately, but studies in this area are insufficient and are conducted only in the context of general problems of financial law, management theory and administrative law. And when it comes to real devolution and extension of financial autonomy of local selfgovernment, it is necessary to introduce special procedures for financial control over the implementation of local budget revenues, as well as audit of financial transactions and settlements ${ }^{21}$.

In legal relations on the local budgets revenue have internal and external financial control.

Internal control is exercised by elected representative bodies of local authorities by special commissions or committees. According to V. Kravchenko, the external financial control of the activity of local authorities is exercised by the state authorities on the line of both executive, legislative and judicial power. External financial control aims to comply with the law in the decisions of local authorities in the financial sphere 22 .

In our view, the establishment of broad financial and administrative autonomy of local authorities at the legislative level in the execution of local budgets on revenues should be accompanied by parallel tight financial control by the state. It is the financial control over the formation of the revenue part of local budgets and the use of local funds that ensures the efficient functioning

${ }^{21}$ Олексій У.О. Парламентський контроль за дотриманням місцевих бюджетів Вісник асоиіаиії фінансового права С. 75, 70-78.

${ }^{22}$ Кравченко В.І. Місцеві фінанси України : навч. посіб. / В.І. Кравченко. - К. : Т-во «Знання», КОО, 1999. - 487 с. - С. 48. 
of local finances, and also ensures that the financial activities of local governments and their officials are observed.

This can be confirmed by the positive experience of foreign countries in implementing effective financial control in the implementation of local budgets for revenues. For example, in Sweden, the external financial control of a commune's activity is exercised only by the legislature and the judiciary.

As for the delegation of powers of state power to local authorities in the area of implementation of local budgets, external financial control also concerns the expediency of actions of local authorities ${ }^{23}$.

In France, special bodies of financial control over the activities of local authorities on filling local budgets - regional accounts chambers - have been set up. These are judicial bodies. Some authority in this area has been given to the prefect - a representative of the government in the regions and departments. It is he who submits to the Regional Chamber of Accounts materials on the financial activities of communes and other local authorities. The Regional Audit Office may oblige a local authority to overturn a contravention of the law. A special procedure for controlling the local budget has also been established. If the budget of the commune is not adopted by March 31 of the current year, or by April 15 of the year of the municipal councils renewal, the prefect of the department immediately appeals to the regional accounting chamber, which makes a public decision within a month. During this period, the commune's budget is governed by the prefect. The municipal council is now losing the right to manage the budget.

In Ireland, all expenditure and revenue items of local governments are controlled within the accounting and auditing system under the guidance of the Minister for the Environment. Local government accounts are audited annually by the central government.

In Austria, financial documents for the implementation of local budgets for the income of any community with a population of more than 20,000 people are to be provided annually to the government of the land and to the tax administration. In Spain, the financial activity of local authorities is controlled by a special court of auditors. In the Netherlands, the government exercises prior control over tax regulations and the municipal budget, the creation of funds, associations, joint ventures, cooperatives and other bodies provided for by civil law.

In Norway, financial transactions such as loans and transfers of fixed assets are subject to prior control. In Portugal, municipal budget

${ }^{23}$ Марущак А. В. Правові основи контролю за виконанням місцевих бюджетів в Україні International scientific and practical conference "Legal practice in EU countries and Ukraine at the modern stage”. Conference proceedings, Arad 2019, p. 394, 393-395. 
implementation reports are first submitted to the Audit Board, which checks them for compliance, and then submits them to the municipal council ${ }^{24}$.

Therefore, we believe that improving the system of state internal control and strengthening the accountability of participants in the budget process in respect of the implementation of local budgets for revenues is a very important task of public authorities today. To do this, the rules on the powers and responsibilities of the bodies empowered to monitor compliance with budget legislation, determine the types of budget offenses, measures of influence and procedures for their application in case of committing budget offenses by the subjects of execution of local budgets by revenues should be carried out.

\section{CONCLUSIONS}

Thus, the relationship of filling the local budgets by income is a specific type of budgetary relationship, which has its own, inherent features and characteristics.

By their nature, they are managerial relationships and aim at matching the actual local budget revenues to the indicators planned in the local budget, these relationships have the meaning of providing budget financing for the implementation of tasks and functions of state and local authorities in a specific administrative and territorial unit.

The main negative tendencies of providing local budgets with incomes in the current conditions are the implementation of this activity in violation of budgetary procedures and "in manual mode".

Among the factors that have a negative impact on the implementation of local budgets are the following:

lack of clear delineation of powers to control the implementation of local budgets, as well as responsibility for budget execution between budget spending units and state authorities on the ground;

insufficient timely, reliable and detailed information on the state of implementation of the budget, which is necessary for making decisions on managing the budget process and bringing the amounts of actual budget expenditures into line with the available resources;

partial discrepancy between local budget performance indicators and territorial socio-economic development indicators.

Local government executive bodies and local self-government bodies are involved in legal relations to replenish local budget revenues as subjects of such legal relations. They are endowed with budgetary competence. The competence of state and local self-government bodies in the area of revenue

${ }^{24}$ Місцеві фінанси : [навч.-метод. посіб. для самост. вивч. дисципліни] / М.А. Гапонюк, В.П. Яцюта, А.С. Буряченко, А.А. Славкова К. : Київ. націон. економ. ун-т, 2002. 184 с. С. 55-56. 
generation by local budgets is established by legal acts, and its implementation is provided by means of state coercion.

All of the above implies the need to improve the legal regulation of the process of obtaining revenues by local budgets. This should be done in order to identify ways to optimize this stage of the budget process in order to effectively influence the socio-economic development of individual territories.

\section{SUMMARY}

The article determines that the legal relations of obtaining revenues of local budgets are governed by the legal norms of relations that are formed between subjects of budgetary law regarding timely and full receipt of money resources in local budget revenue of a certain level for budgetary financing of ensuring tasks and functions that are performed by public authorities and local self-government in the territory of a certain administrative-territorial unit of Ukraine.

It is established that the result of these relationships is the complete and timely receipt of all planned budgetary revenues, which allows to report on its full implementation. When executing the local budget, revenues and taxes are collected in accordance with the procedure approved by the budget and tax legislation, therefore the authorities are obliged to control these activities.

Financial control is a means of ensuring compliance with financial and planning discipline, as well as ensuring the effective implementation of local budgets. Due to the financial control, the budget and the effective execution of the budget are achieved both in terms of revenues and expenditures, as it is an effective instrument for combating crimes in the sphere of financial relations, a means of preserving state and communal property and funds, which is of particular importance at the stage of establishing market relations in Ukraine.

\section{REFERENCES}

1. Львов Д. Курс финансового права. Казань : Тип. Император. ун-та, 1887. $-521 \mathrm{c.}$

2. Воблый К.Г. Начальный курс политической экономии : (История, теория, финансы) : пособ. для коммерч., технич. училищ и для самообразов. с 6 диаграммами в тексте / К.Г. Воблый ; Киев. юрид. ин-т. Киев : Т-во печ. и изд. дела авт.-изд. «Голос», 1918. 252 с.

3. Иловайский С.И. Краткий учебник финансового права Одесса : Типография шт. войск Одесского военного округа, 1893. 297 с

4. Загородній А.Г. Фінансовий словник. / Загородній А.Г., Вознюк Г.Л., Смовженко Т.С. Львів : Центр Європи, 1997. 576 с.

5. Фінансове право : підручник / Л.К. Воронова. - Х. : Консум, 1999. -496 c. - C. 180. 
6. Воронова Л.К. Фінансове право : підручник / Л.К. Воронова. К. : Прецедент; Моя книга, 2006. 448 с.

7. Чернадчук В.Д. Стан та перспективи розвитку бюджетних правовідносин в Україні : монографія / В.Д. Чернадчук. Суми : ВТД «Університетська книга», 2008. 456 с.

8. Василик О.Д. Бюджетна система України : підручник / О.Д. Василик, К.В. Павлюк. - К. : Центр навч. л-ри, 2004. 544 с.

9. Романенко О.Р. Фінанси : підручник / О.Р. Романенко К. : Центр навч. літератури, 2006. 312 с.

10. Економічна енциклопедія : у 3 т. / відп. ред. С.В. Мочерний та ін. К. : Вид-во центр «Академія». Т. 1. 2000. 864 с.

11. Пауль А.Г. Процессуальные нормы бюджетного права / А.Г. Пауль. СПб : Питер, 2003. 208 с.

12. Чернадчук В.Д. Стан та перспективи розвитку бюджетних правовідносин в Україні : монографія / В.Д. Чернадчук. Суми : ВТД «Університетська книга», 2008. 456 с.

13. Гнатовська А.I. Загальна характеристика об'єктів бюджетних правовідносин. Європейські перспективи. 2011. № 1. С. 108-112.

14. Правовий статус суб'єктів виконання місцевих бюджетів за доходами : монографія / Т.А. Латковська, А.І. Гнатовська. Одеса : Фенікс, 2014. 228 с.

15. Latkovska T., Kasianenko L.M. Procedural norms in the financially-legal regulation Public finance: legal aspects: Collective monograph Riga : Izdevnieciba «Baltija Publishing». P. 80-94.

16. Алисов Е.А. Финансовое право Украины : учеб. пособ. Х. : Эспада, 2000. 288 с.

17. Дмитрик О.А. Содержание и классификация финансовых правоотношений : монография / О.А. Дмитрик ; под ред. Н.П. Кучерявенко. Х. : Легас, 2004. 160 с.

18. Музика-Стефанчук О.А. Органи публічної влади як суб’єкти бюджетних правовідносин / О.А. Музика-Стефанчук. Хмельницький : Вид-во Хмельн. ун-ту управл. та права, 2011. 384 с.

19. Чернадчук В.Д. Стан та перспективи розвитку бюджетних правовідносин в Україні : монографія / В.Д. Чернадчук. Суми : ВТД «Університетська книга», 2008. 456 с.

20. Бюджетний кодекс України від 08.07.2010 p. Вiдомості Верховної Ради України. 2010. № 50-51. Ст. 572.

21. Олексій У.О. Парламентський контроль за дотриманням місцевих бюджетів Вісник асоціації фінансового права С. 70-78.

22. Кравченко B.I. Місцеві фінанси України : навч. посіб. / В.І. Кравченко. К. : Т-во «Знання», КОО, 1999. 487 с. 
23. Марущак А. В. Правові основи контролю за виконанням місцевих бюджетів в Україні International scientific and practical conference "Legal practice in EU countries and Ukraine at the modern stage". Conference proceedings, Arad. 2019, p. 393-395

24. Місцеві фінанси : [навч.-метод. посіб. для самост. вивч. дисципліни] / М.А. Гапонюк, В.П. Яцюта, А.С. Буряченко, А.А. Славкова. К. : Київ. націон. економ. ун-т, 2002. 184 с.

Information about the author: Hnatovska A. I., Candidate of JuridicalSciences, Associate Professor, Senior Lecturer at the Departmentof Constitutional, Administrative and Finance Law, Chernivtsi Law Institute of the National University "Odessa Law Academy"

7, Skovorody str., Chernivtsi, 58000, Ukraine

ORCID ID: orcid.org/0000-0001-7171-3209 